\title{
Palmyra Atoll
}

National Cancer Institute

\section{Source}

National Cancer Institute. Palmyra Atoll. NCI Thesaurus. Code C123767.

An atoll in the North Pacific Ocean halfway between Hawaii and American Samoa. 